\title{
PENGEMBANGAN BUKU AJAR STATISTIKA PENDIDIKAN I (DESKRIPTIF) UNTUK MAHASISWA PENDIDIKAN AGAMA ISLAM UNIVERSITAS ISLAM RIAU
}

\author{
Sari Herlina ${ }^{*}$, Endang Istikomah ${ }^{1}$ \\ ${ }^{1}$ Program Studi Pendidikan Matematika, Universitas Islam Riau \\ *Email korespondensi: sariherlina99@edu.uir.ac.id
}

\begin{abstract}
ABSTRAK
Penelitian ini dilatarbelakangi kesulitan mahasiswa dalam mamahami materi dari buku-buku statistik yang beredar yang harus disesuaikan dengan Satuan Acara Perkuliahan (SAP). Oleh karena itu, peneliti mengembangkan buku ajar Statistika Pendidikan I (Deskriptif) untuk mahasiswa Pendidikan Agama Islam di Universitas Islam Riau yang disesuaikan SAP dengan menyajikan bahan ajar modul dengan bahasa yang sederhana diharapkan dapat membuat mahasiswa termotivasi dalam belajar statistika. Metode penelitian yang digunakan adalah Research and Development (R\&D) dengan model ADDIE. Pengembangan bahan ajar modul ini terdiri dari 5 tahap rancangan pengembangan. Tahap pertama adalah analisis kebutuhan, tahap kedua membuat rancangan/desain, tahap ketiga pengembangan bahan ajar modul statistika pendidikan I (Deskriptif) dengan memvalidasi media yang dikembangkan, tahap keempat adalah implementasi dengan mencobakan bahan ajar matematika yang dikembangkan, dan tahapan terakhir adalah evaluasi terhadap buku ajar yang dikembangkan. Dalamn penelitian ini tahapan yang akan dilakukan sampai tahap validasi modul dan mengambil respon mahasiswa. Instrumen penelitian dan pengumpul data yang digunakan berupa lembar validasi ahli pembelajaran dan angket respon mahasiswa terhadap buku ajar Statistika Pendidikan 1 (Deskriptif) yang telah dikembangkan. Teknik analisis data yang dilakukan dengan menganalisis lembar validasi ahli pembelajaran dan menganalisis respon mahasiswa terhadap buku ajar Statistika Pendidikan 1 (Deskriptif) yang telah dikembangkan. Hasil penelitian menunjukkan bahwa hasil uji validasi buku ajar Statistika Pendidikan 1 (Deskriptif) yaitu 78\% dengan kriteria valid dan kualifikasi baik. Hasil respon mahasiswa menunjukkan respon positif dengan respon terhadap buku ajar ini. Respon yang diberikan dari 69 mahasiswa yaitu 39,7\% menyatakan sangat setuju dan $60 \%$ setuju dengan adanya buku ajar Statistika Pendidikan 1 (Deskriptif).
\end{abstract}

Kata Kunci: Buku Ajar, Statistika, Pengembangan, ADDIE.

\begin{abstract}
This research is motivated by the difficulties of students in understanding material from statistical books that have to be adjusted to the Lecture Program Unit (LPU). Therefore, the researchers developed the Education Statistics I textbook (Descriptive) for Islamic Religious Education students at the Islamic University of Riau, which was adjusted by LPU by presenting module teaching materials in simple language, which is expected to make students motivated in learning statistics. The research method used is Research and Development (R\&D) with the ADDIE model. The development of
\end{abstract}


teaching materials in this textbook consists of 5 stages of development design. The first stage is the needs analysis, the second stage is making a design, the third stage is the development of teaching materials for education statistics I (Descriptive) textbook by validating the developed media, the fourth stage is implementation by trying out the developed mathematics teaching materials, and the last stage is the evaluation of the modules which was developed. In this study the stages will be carried out until the module validation stage and take student responses. The research instrument and data collected use form of a validation sheet of experts person and student questionnaire responses to the textbook teaching materials that have been developed. The data analysis technique was carried out by analyzing the learning expert validation sheets and analyzing the students' responses to the Education Statistics 1 textbook (Descriptive) that had been developed. The results showed that the results of the Education Statistics 1 (Descriptive) textbook validation were $85.1 \%$ with valid criteria and very good qualifications. The results of student responses showed positive responses with responses to this textbook. The responses given from 69 students namely $39.7 \%$ stated strongly agree and $60 \%$ agree with the existence of Education Statistics 1 (Descriptive) textbook.

Keywords: Textbook, Statistics, development, ADDIE.

\section{PENDAHULUAN}

Setiap dosen mempunyai kewajiban melaksanakan Tri Dharma Perguruan Tinggi, yaitu: Pengajaran; Penelitian; dan Pengabdian. Dalam kegiatan pengajaran seorang dosen mempunyai kewajiban untuk melaksanakan pembelajaran yang kreatif serta inovatif sehingga bisa mencapai tujuan belajar. Selain itu, untuk mendukung proses pembelajaran seorang dosen harus membuat buku ajar, buku teks sebagai salah satu sumber belajar dan untuk pengembangan budaya akdemik serta pembudayaan kegiatan baca tulis bagi Sivitas Akdemika (UU No. 12 Tahun 2012, Bab 1(3) :13). Dengan mengembangkan buku ajar atau buku teks dapat tercapainya fungsi pendidikan tinggi yaitu: mengembangkan Sivitas Akademika yang inovatif, kreatif, terampil, berdaya saing, kooperatif serta mengembangkan Ilmu pengetahuan (UU No. 12 Tahun 2012, Pasal 4: 6).

Buku ajar yang dikembangkan dapat dilakukan berdasarkan matakuliah yang diampu. Salah satu matakuliah yang peneliti ampu adalah matakuliah Statistika Pendidikan. Susetyo (2014: 2) mengungkapkan bahwa statistika merupakan pengetahuan yang berkaitan dengan cara pengumpulan data, mengolah atau menganalisis data, serta menarik suatu kesimpulan berdasarkan data yang dikumpulkan dan analisis yang dilakukan. Sehingga matakuliah ini merupakan matakuliah wajib untuk semua program studi karena nantinya dapat berguna untuk penelitian kuantitatif mereka.

Kenyataan di lapangan menunjukkan mahasiswa yang bukan dalam bidang matematika cendrung tidak menyukai matakuliah ini, hal ini berdasarkan observasi yang dilakukan setelah beberapa kali mengajar dengan angkatan yang berbeda. Pada umumnya mahasiswa 
mengambil jurusannya karena ingin menghindari matematika. Asumsi matematika itu sulit masih dominan. Namun mahasiswa harus mengikuti perkuliahan tersebut. Walaupun buku teks tentang Statistika sudah banyak beredar, namun hal tersebut malah membuat mereka bingung dalam memahami materi statistika. Setelah dilakukan wawancara dengan beberapa mahasiswa ditemukan bahwa setiap buku ada simbol-simbol berbeda, rumus yang berbedabeda untuk beberapa konsep, seperti mencari rata-rata dan deviasi standar. Selain itu, kebanyakan buku tidak diawali konsep dasar-dasar analisis yang diperlukan untuk memahami konsep matakuliah statistika.

Dalam proses pembelajaran buku ajar yang digunakan masih buku ajar statistika yang sudah ada. Setiap mahasiswa hanya diwajibkan membawa buku ataupun bahan sesuai dengan Satuan Acara Perkuliahan (SAP) yang telah peneliti buat. Hal ini menyebabkan mahasiswa kesulitan memahami konsep dengan buku yang bervariasi antara mereka, sehingga pencapaian tujuan pembelajaran jadi tidak maksimal.

Berdasarkan permasalahan tersebut, peneliti ingin membuat bahan ajar. Bahan ajar ada beberapa jenis (Daryanto, 2014: 173), bahan ajar yang akan dikembangkan peneliti berupa buku ajar. Buku ajar Statistika Pendidikan I (Deskriptif) ini diharapkan dapat memudahkan mahasiswa memahami materi tersebut. Dengan adanya bahan ajar dalam bentuk buku ajar ini, dapat dijadikan oleh mahasiswa sebagai sarana belajar mandiri berdasarkan kecepatan belajar mereka masing-masing. Sehingga peneliti tertarik untuk melakukan penelitian yang berjudul Pengembangan Buku Ajar Statistika Pendidikan I (Deskriptif) pada mahasiswa pendidikan

agama Islam di Universitas Islam Riau. Dengan demikian, tujuan dari penelitian ini 1. untuk melihat dan menganalisis hasil validasi pengembangan desain bahan ajar statistika pendidikan I (Deskriptif) pada mahasiswa pendidikan Agama Islam di Universitas Islam Riau, 2. Untuk melihat dan menganalisis respon mahasiswa terhadap buku ajar statistika pendidikan I (Deskriptif) yang dikembangkan.

\section{METODE PENELITIAN}

Jenis penelitian ini adalah penelitian pengembangan atau Research and Development (R\&D). R \& D dalam pendidikan adalah suatu penelitian yang digunakan untuk merancang produk dan prosedur baru yang kemudian secara sistematis diuji lapangan, dievaluasi, dan disempurnakan sampai memenuhi kriteria tertentu, yaitu Efektivitas dan berkualitas (Gold, Gall, \& Borg dalam Putra, 2015: 84). Model pengembangan dalam penelitian ini 
menggunakan model ADDIE, dengan tahapan yaitu: Analysis; Design; Development; Implementation; Evaluation (Mulyaningsih, 2016). Prosedur pengembangan yang akan dilakukan dalam penelitian ini sebagai berikut:

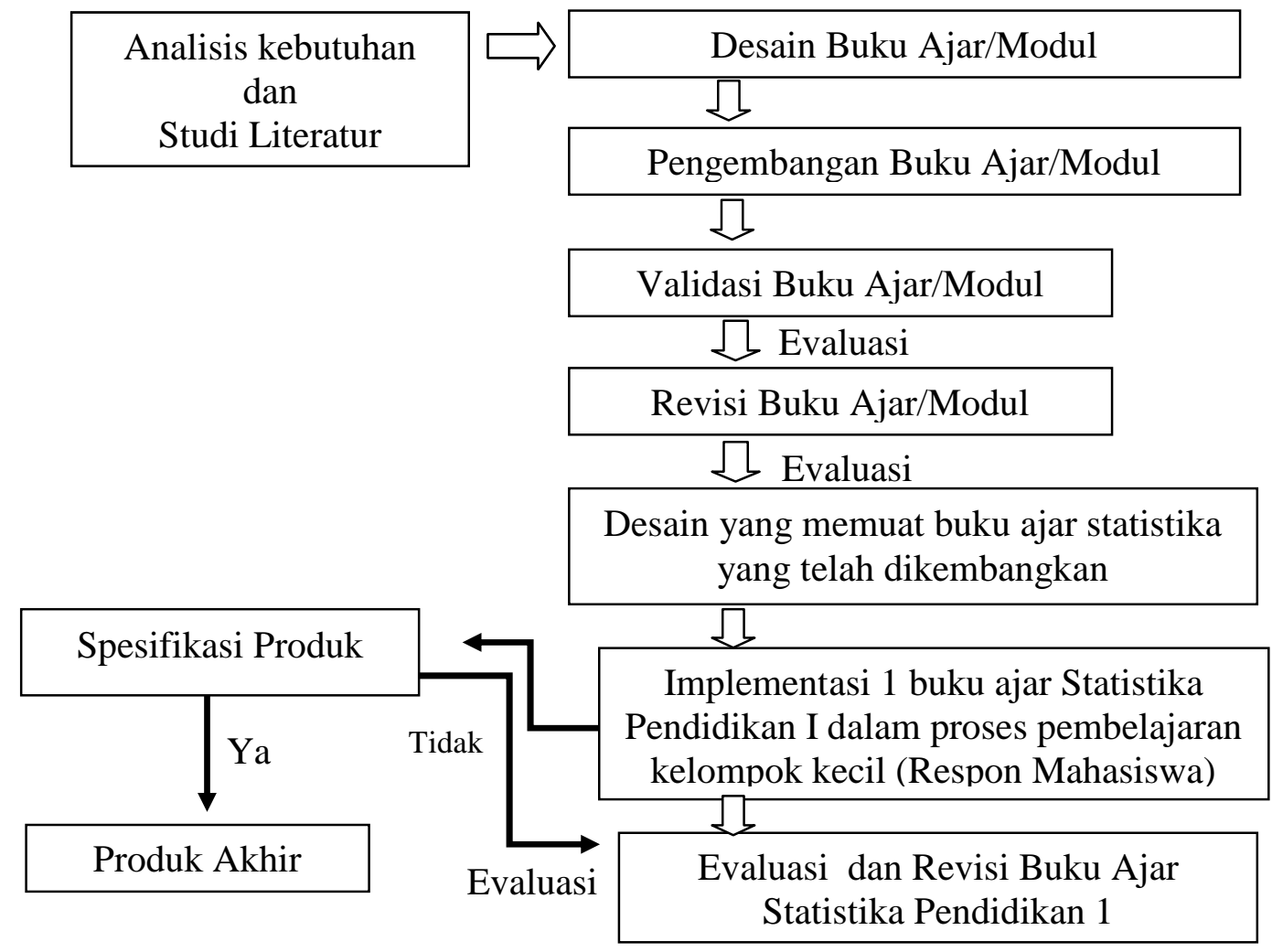

Gambar 1. Prosedur Pengembangan Buku Ajar

Instrumen penelitian dan pengumpul data yang digunakan berupa lembar validasi ahli pembelajaran dan angket respon mahasiswa terhadap buku ajar Statistika Pendidikan 1 yang telah dikembangkan. Teknik analisis data yang dilakukan dengan menganalisis lembar validasi ahli pembelajaran dan menganalisis respon mahasiswa terhadap buku ajar Statistika Pendidikan 1 (Deskriptif) yang telah dikembangkan. Untuk menguji kelayakan dan validasi produk buku ajar yang dikembangkan ditentukan kriteria berikut:

Tabel 1. Kategori Kelayakan dan Validasi Produk

\begin{tabular}{ccc}
\hline $\begin{array}{c}\text { Tingkat Pencapaian } \\
(\%)\end{array}$ & Kualifikasi & Kategori \\
\hline $81-100$ & Sangat Baik & Valid \\
$61-80$ & Baik & Valid \\
$41-60$ & Cukup & Tidak Valid \\
$21-40$ & Kurang & Tidak Valid \\
$0-20$ & Sangat Kurang & Tidak Valid \\
\hline
\end{tabular}


Kegiatan analisis data dilakukan berdasarkan tahapan pengembangan buku ajar Statistik Pendidikan 2 berikut:

Tabel 2. Tahapan Analisis Data Pengembangan Buku Ajar Statistika Pendidikan 1

\begin{tabular}{|c|c|c|c|c|c|c|}
\hline $\begin{array}{c}\text { Tujuan } \\
\text { Penilaian }\end{array}$ & Indikator & Instrumen & Sumber Data & $\begin{array}{l}\text { Data yang } \\
\text { diperoleh }\end{array}$ & $\begin{array}{c}\text { Teknik } \\
\text { Analisis } \\
\text { Data }\end{array}$ & $\begin{array}{c}\text { Kriteria } \\
\text { yang } \\
\text { diharapkan } \\
\end{array}$ \\
\hline $\begin{array}{l}\text { Kevalidan } \\
\text { Buku Ajar }\end{array}$ & $\begin{array}{l}\text { Komponen } \\
\text { buku ajar } \\
\text { Statistika } \\
\text { Pendidikan 1 } \\
\text { (Deskriptif) } \\
\text { yang valid } \\
\text { dan layak }\end{array}$ & $\begin{array}{l}\text { Angket } \\
\text { Validasi }\end{array}$ & $\begin{array}{l}2 \text { orang } \\
\text { validator }\end{array}$ & Skor & $\begin{array}{l}\text { Rata-rata } \\
\text { persentase } \\
\text { hasil } \\
\text { validasi } \\
\text { dari dua } \\
\text { orang } \\
\text { validator }\end{array}$ & $\begin{array}{l}\text { Valid dan } \\
\text { Layak }\end{array}$ \\
\hline $\begin{array}{l}\text { Respon } \\
\text { Buku Ajar }\end{array}$ & $\begin{array}{l}\text { Komponen } \\
\text { buku ajar } \\
\text { untuk } \\
\text { melihat } \\
\text { respon }\end{array}$ & $\begin{array}{l}\text { Angket } \\
\text { Respon } \\
\text { menggunakan } \\
\text { google form }\end{array}$ & $\begin{array}{l}\text { Mahasiswa } \\
\text { yang } \\
\text { mengikuti } \\
\text { perkuliahan } \\
\text { statistika } \\
\text { pendidikan }\end{array}$ & Skor & $\begin{array}{l}\text { Rata-rata } \\
\text { persentase } \\
\text { respon dari } \\
\text { mahasiswa }\end{array}$ & $\begin{array}{l}\text { Respon } \\
\text { Positif }\end{array}$ \\
\hline
\end{tabular}

\section{HASIL DAN PEMBAHASAN}

\section{Hasil Penelitian}

Penelitian dan Pengembangan buku ajar statistika pendidikan 1 (Deskriptif) ini telah divalidasi oleh dua orang validator dan mendapatkan respon dari 69 orang mahasiswa. buku Ajar Statistik Pendidikan 1 ini terbagi atas enam bab. Uraian materi tiap bab diuraikan sebagai berikut:

Tabel 3. Daftar Materi pada Buku Ajar

\begin{tabular}{cl}
\hline BAB dalam Buku Ajar & \multicolumn{1}{c}{ Materi } \\
\hline BAB-1 & Pengantar Dasar Statistika \\
BAB-2 & Penyajian Data \\
BAB-3 & Ukuran Tendensi Sentral \\
BAB-4 & Ukuran Penyebaran Data \\
BAB-5 & Ukuran Keruncingan dan Kemiringan \\
BAB-6 & Distribusi Gauss \\
\hline
\end{tabular}


Buku ajar Statistika Pendidikan 1 terdiri dari cover, daftar isi, materi setiap bab, learning outcome, soal-soal latihan, glosarium dan indeks buku. Desain dari buku ajar ini sebagai berikut:

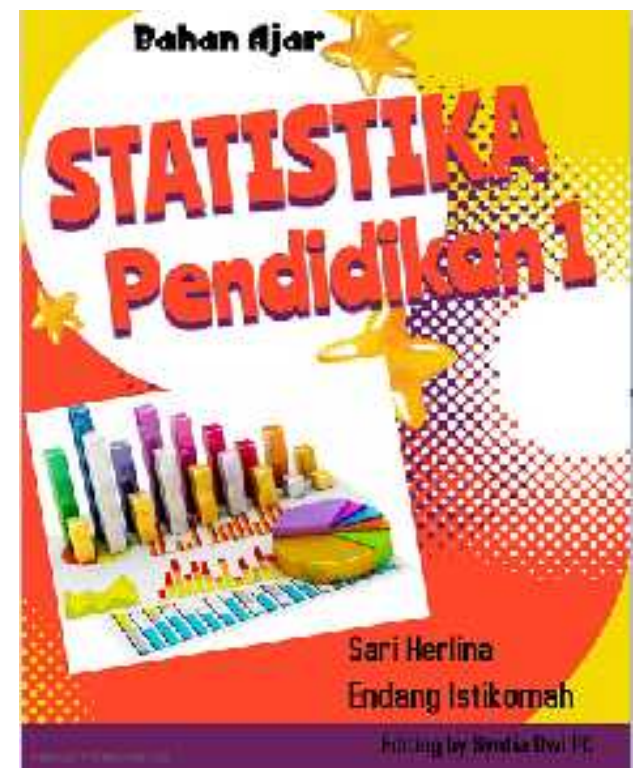

Gambar 1. Bagian Cover

Pada bagian cover buku ini, salah satu validator menyatakan menarik, sedangkan yang satu lagi kurang menarik karena terlalu banyak warna. Cover ini nantinya akan didesain lagi agar lebih netral dan disukai semua pihak yang menggunakan buku ini.

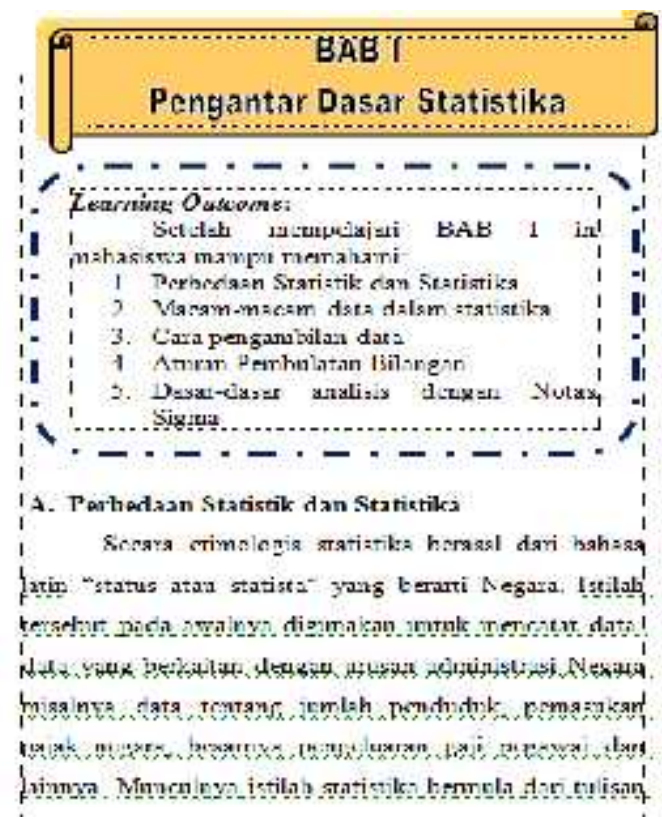

Gambar 2. Bagian Bab pada Buku Ajar 
Bagian ini merupakan salah satu bagian dalam buku ajar. Masukkan dari validator agar menambah tujuan pembelajaran dan learning outcome yang akan dicapai menyesuaikan lagi berdasarkan KKNI untuk tingkat perguruan tinggi.

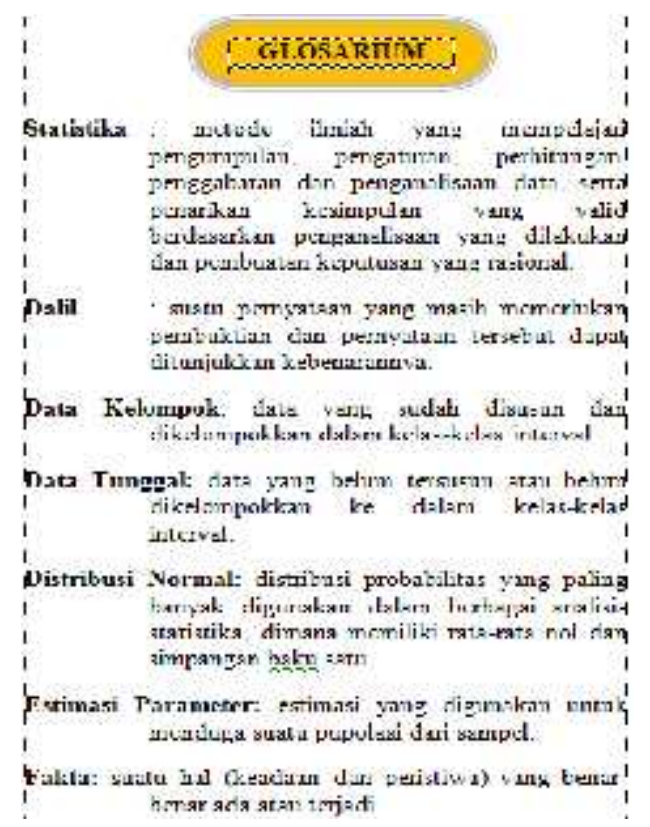

Gambar 3. Glosarium dalam Buku Ajar

Pada bagian glosarium validator sudah menyatakan sangat baik. Setelah buku ajar statistika Pendidikan selesai didesain, kegiatan selanjutnya adalah melakukan validasi ke validator kemudian meminta respon mahasiswa terhadap modul yang sudah dikembangkan. Hasil validasi dan respon mahasiswa diuraiakan sebagai berikut:

\section{1) Analisis Hasil Validasi}

Hasil validasi buku ajar statistika pendidikan 1 (Deskriptif) ini divalidasi oleh dua orang ahli. Di dalam lembar validasi terdapat lima Aspek penilaian yaitu: Content (isi), Konstruk/Penyajian, Bahasa, Kegrafisan dan Efesiensi. Hasil validasi dari validatror dirangkum dalam tabel berikut:

Tabel 4. Aspek Penilaian Lembar Validasi

\begin{tabular}{llcccc}
\hline \multirow{2}{*}{ No } & Aspek yang dinilai & \multicolumn{2}{c}{ Penilaian $(\%)$} & Rata-rata total & Kualifikasi \\
\cline { 3 - 3 } & & Validator-1 & Validator-1 & & \\
1 & Content (isi) & 81,7 & 76,7 & 79,20 & Baik \\
2 & Konstruk/Penyajian & 77,5 & 72,5 & 75,00 & Baik \\
3 & Bahasa & 90 & 75 & 82,50 & Sangat Baik \\
4 & Kegrafisan & 81,3 & 75 & 78,15 & Baik \\
5 & Efesiensi & 87,5 & 75 & 81,25 & Sangat Baik \\
& $\quad$ Total & 83,6 & 74,84 & 79,22 & Baik \\
\hline
\end{tabular}


Berdasarkan hasil validasi oleh validator terlihat bahwa aspek penilaian dari bahasa dan efesiensi buku ajar ini mendapat kualifikasi sangat baik, sedangkan dari segi konten, konstruk dan kegrafisan memeroleh kualifikasi baik. Hal ini menunjukkan bahwa bahasa yang digunakan sudah sederhana dan efesien untuk digunakan. Buku ajar ini dirancang untuk mahasiswa Pendidikan Agama Islam yang pada umumnya tidak menyukai matematika. sehingga memerlukan bahasa yang sederhana dan simbol-simbol yang konsisten untuk memudahkan dalam memahami konsep statistik. Dari sisi konten maupun kegrafisan ada beberapa masukan dari validator seperti: 1) perlu tambahan materi pada bagian ukuran tendensi sentral, 2) menambahkan tujuan pembelajaran yang diturunkan dari learning outcome; 3) margin dari buku perlu diperhatikan lagi; 4) leaning outcome menyesuaikan dengan KKNI; 5) pada Bab V dan Bab VI masih minim materinya; 6) cover kurang menarik karena terlalu ramai warna; 7) perlu menambah tes formatif dan kunci jawaban sebagai panduan belajar mandiri bagi mahasiswa.

\section{2) Analisis Hasil Respon Mahasiswa}

Setelah melakukan validasi terhadap bahan ajar Statistika Pendidikan 1 ini, peneliti meminta respon mahasiswa. Respon mahasiswa ini diambil dari tiga kelas dengan total mahasiswa hampir 120 mahasiswa. Namun yang memberikan respon 69 orang. Indokator respon mahasiswa ini terdiri dari tiga aspek yaitu: ketertarikan materi dan bahasa. Angket respon dibuat melalui googleform untuk memudahkan dalam pengumpulan data. Hasil respon mahasiswa secara keseluruhan dari segi ketertarikan pada bahan ajar Statistika yaitu 39,7\% menyatakan sangat setuju, dan 60,3\% menyatakan setuju sedangkan yang menyatakan kurang setuju dan tidak setuju tidak ada. Hal ini menunjukkan ada respon positif mahasiswa terhadap buku ajar statistika pendidikan 1 yang dikembangkan.

\section{Pembahasan}

Pengembangan buku ajar Statistik Pendidikan 1 ini didasari atas analisis peneliti melihat kondisi kesulitan mahasiswa yang tidak dibidang matematika dalam memahami konsep statistika, padahal matakuliah statistika merupakan matakuliah wajib. Kesulitan itu dikarenakan banyaknya buku statistika yang beredar dipasaran sehingga setiap buku biasanya punya simbolisasi sendiri terhadap rumus atau konsep tertentu, misal panjang kelas, ada buku yang menulis dengan lambang p, 1 atau c. Hal ini menjadikan mahasiswa bingung. Selain itu, 
buku ajar statistika Pendidikan 1 ini mengacu kebutuhan mahasiswa untuk memahami dan mengaplikasikan konsep statistik dari analisis deskriptif ke analisis inferensial. Depdiknas (2008) mengungkapkan bahwa bahan ajar yang baik memperhatihan kebutuhan siswa dan dapat dijadikan bahan alternatif bahan ajar. Jadi, Buku ajar statistika Pendidikan 1 ini sudah disajikan dengan bahasa yang sederhana dan mudah dipahami sesuai kebutuhan mahasiswa, sehingga mahasiswa yang tidak menyukai matematika bisa mengaplikasikannya untuk keperluan penelitian atau dalam kehidupannya.

Hasil pengembangan buku ajar Statistika Pendidikan 1 ini valid dan layak digunakan dengan hasil validasi 79,22\% dengan kualifikasi baik. Hasil validasi ini menjadi perbaikan terhadap buku ajar yang dikembangkan. Selain itu, hasil respon mahasiswa juga positif. Ini menunjukkan buku ajar Statistika Pendidikan 1 ini siap untuk digunakan dalam proses pembelajaran. Hal ini sesuai yang diuangkapkan Juliana, dkk (dalam Ramdani \& Dini, 2016) bahwa kriteria yang digunakan untuk memutuskan media pembelajaran yang dibuat memiliki tingkat validitas yang memadai apabila nilai validasi keseluruhan pada media pada kategori valid.

Produk akhir dari penelitian ini masih pada tahap buku ajar Statistika Pendidikan 1 (Deskriptif) yang telah divalidasi dan memperoleh respon mahasiswa. Produk buku ajar statistika ini perlu dilakukan penggunaan dalam proses pembelajaran sehingga teruji keefektifannya. Dengan demikian, buku ajar Statistik Pendidikan ini sudah layak untuk dapat digunakan dalam kelompok yang lebih luas.

\section{KESIMPULAN}

Penelitian pengembangan ini menghasilkan buku ajar Statistika Pendidikan 1 (Deskriptif) yang dapat digunakan dalam pembelajaran. Hasil penelitian menunjukkan bahwa hasil validasi buku ajar Statistika Pendidikan 1 (Deskriptif) yaitu 78\% dengan kriteria valid dan kualifikasi baik. Hasil respon mahasiswa menunjukkan respon positif dengan respon terhadap buku ajar ini. Respon yang diberikan dari 69 mahasiswa yaitu 39,7\% menyatakan sangat setuju dan 60\% setuju dengan adanya buku ajar Statistika Pendidikan 1 (Deskriptif). Buku ajar ini masih perlu dilakukan uji pada kelompok terbatas dan kelompok yang lebih luas untuk dapat ditinjau tingkat kepratisan dan keefetifannya dalam proses pembelajaran. 


\section{REKOMENDASI}

Rekomendasi yang dapat peneliti sampaikan berdasarkan hasil penelitian ini adalah buku ajar statistika pendidikan 1 ini rekomended untuk digunakan bagi mahasiswa yang akan mengikuti perkuliahan statistik.

\section{UCAPAN TERIMAKASIH}

Peneliti mengucapkan terimakasih kepada pihak Lembaga Penelitian dan Pengabdian kepada Masyarakat (LPPM) UIR yang telah mendanai kegiatan penelitian ini. Peneliti juga mengucapkan terimakasih kepada validator yaitu Sindi Amelia, M.Pd dan Aulia Sthephani, M.Pd yang telah memeberikan tenaga dan pikirannya untuk memvalidasi buku ajar Statistik Pendidikan 1 ini.

\section{REFERENSI}

Daryanto \& Aris D. (2014). Pengembangan Perangkat Pembelajaran (Silabus, RPP, PHB, Bahan Ajar). Yogyakarta: Gava Media.

Daryanto. (2013). Menyusun Modul: Bahan Ajar untuk Persiapan Guru dalam Mengajar. Yogyakarta: Gava Media.

Departemen Pendidikan Nasional. (2008). Pengembangan Bahan Ajar. Depdiknas Jakarta: Direktorat Dikmenum.

Juliana, Kartika, dkk. (2016). Pengembangan Buku Ajar Mata Kuliah Biologi Sel Dengan Pendekatan Bioinfarmatika untuk Mahasisiwa S1 Pendidikan Biologi Universitas Malang: Junal Pendidikan. Vol. 1, No. 9 (hal1680-1681). Malang: Universitas Negeri Malang.

Majid, A. (2008). Perencanaan Pembelajaran: Mengembangkan Standar Kompetensi Guru. Bandung: PT. Remaja Rosdakarya.

Mulyaningsih. (2016). Pengembangan Model Pembelajaran. Tersedia: [PDF] Pengembangan Model Pembelajaran E Mulyatiningsih - ... -mulyatiningsih-mpd/7cpengembanganmodel ..., 2016 - staff.uny.ac.id

Putra, N. (2015). Reseach and Development. Jakarta: PT. Raja Grafindo.

Sugiyono. (2001). https://www.scribd.com/document/359411371/SUGIYONO-METODEPENELITIAN-DAN-PENGEMBANGAN-pdf.

Susetyo, B. (2014). Statistika Untuk Analisis Data Penelitian (Dilengkapi Cara Perhitungan dengan SPSS dan MS. Office Excel). Bandung: PT. Refika Aditama. 
23 SUPERMAT, Volume 3, No. 2, November 2019, hal. 13-23

Tegeh, I., \& Made. (2015). Pengembangan Buku Ajar Model Penelitian Pengembangan Dengan Model ADDIE. Seminar Nasional Riset Inovatif IV. 